\title{
Kadar IL-10 Mencit Balb/C Terinfeksi Plasmodium berghei dengan Pemberian Fraksi Metanol Bangle (Zingiber cassumunar Roxb.) sebagai Terapi Komplementer
}

\author{
(The IL-10 level of Plasmodium berghei-infected Balb/C Mice \\ after Methanolic Fraction of Bangle (Zingiber cassumunar Roxb.) \\ administration as a Complementary Therapy)
}

\author{
Asis Fitriana, Bagus Hermansyah, Muhammad Afiful Jauhani, Wiwien Sugih Utami \\ Program Studi Pendidikan Dokter Fakultas Kedokteran Universitas Jember \\ Jl. Kalimantan no.37 Tegalboto Jember \\ e-mail: wiwien.dr@gmail.com
}

\begin{abstract}
Malaria is an infectious disease caused by Plasmodium spp. The cause of mortality in malaria is the parasite's resistance to malaria drugs and immune system problem. Interleukin-10 is an antiinflammatory cytokine during plasmodium infection. Bangle is a herbal remedy that contains high amount of curcumin showing immunostimulant activity. The purpose of this study was to determine the difference of IL-10 level in Plasmodium berghei-infected Balb/C mice given with methanolic fraction of bangle (Zingiber cassumunar Roxb.) as a complementary therapy. This study was a true experimental with posttest control group design using 25 mice Balb/c which divided into 5 groups (A, B, C, D and E). All groups except group $A$ were infected with $P$. berghei. After positively infected, group $B$ was not treated, $C$ was treated with artemisinin, group $D$ was given with artemisinin and methanolic fraction bangle 0,017 $\mathrm{mg} / \mathrm{gBW}$, group $E$ was treated with methanolic fraction bangle $0,017 \mathrm{mg} / \mathrm{gBW}$. The result showed that group $D$ had the highest-level of IL-10 among the treatment groups. The Post Hoc LSD test showed $p$ value $\geq 0,05$. In conclusion, there was no significant difference of IL-10 serum level in P. berghei-infected Balb/C mice given with methanolic fraction of bangle (Z. cassumunar Roxb.) as complementary therapy.
\end{abstract}

Keywords: Interleukin-10, Plasmodium berghei, Bangle (Zingiber cassumunar Roxb.)

\begin{abstract}
Abstrak
Malaria adalah penyakit infeksi yang disebabkan oleh Plasmodium spp. Mortalitas akibat malaria adalah hasil dari resistensi parasit terhadap Obat Anti Malaria (OAM) dan ketidakseimbangan sistem imun. Interleukin-10 merupakan sitokin anti-inflamasi pada infeksi malaria. Bangle merupakan obat herbal dengan kandungan curcumin tinggi dan mempunyai efek imunostimulan. Tujuan penelitian ini adalah untuk mengetahui perbedaan kadar IL-10 mencit Balb/C terinfeksi Plasmodium berghei dengan pemberian fraksi metanol bangle (Zingiber cassumunar Roxb.) sebagai terapi komplementer. Penelitian ini menggunakan true experimental dengan rancangan posttest control group yang menggunakan subjek 25 ekor mencit Balb/c dibagi menjadi 5 kelompok (A, B, C, D dan E). Semua kelompok kecuali kelompok A diinfeksi $P$. berghei, setelah positif terinfeksi, kelompok $\mathrm{B}$ tidak diberikan terapi, kelompok $\mathrm{C}$ diberikan terapi artemisinin, kelompok D diberikan terapi artemisinin dan fraksi metanol bangle $0,017 \mathrm{mg} / \mathrm{gBB} / \mathrm{har}$, kelompok E diberikan terapi fraksi metanol bangle $0,017 \mathrm{mg} / \mathrm{gBB} /$ hari. Hasil penelitian menunjukkan bahwa kadar IL-10 serum kelompok D mempunyai nilai kadar IL-10 tertinggi diantara kelompok perlakuan. Uji Post Hoc LSD menunjukkan nilai $p \geq 0,05$. Kesimpulannya, bahwa tidak didapatkan perbedaan bermakna kadar IL-10 mencit Balb/C terinfeksi $P$. berghei dengan pemberian fraksi metanol bangle (Z. cassumunar Roxb.) sebagai terapi komplementer.
\end{abstract}

Kata kunci: Interleukin-10, Plasmodium berghei, Bangle (Zingiber cassumunar Roxb.) 


\section{Pendahuluan}

Penyakit malaria sampai saat ini masih menjadi masalah yang utama dalam skala Internasional maupun Nasional. World malaria report tahun 2015, kasus malaria di dunia mencapai 214 juta dan diperkirakan 438 ribu orang meninggal [1]. Pada tahun 2013 di Indonesia, insiden malaria sebesar 1,9\% [2]. Sedangkan di Kabupaten Jember ditemukan 46 kasus [3]. Penyebab mortalitas adalah akibat malaria berat seperti malaria serebral, anemia berat, dan gagal ginjal akut yang secara patofisiologi merupakan akibat dari overproduksi dari sitokin pro-inflamasi seperti TNF- $\alpha$, IFN- $\mu$, IL-1 dan radikal bebas seperti ROI, ROS, dan $\mathrm{NO}$ oleh sel-sel fagosit dan sel endotel yang teraktivasi [4].

Interleukin-10 (IL-10) adalah sitokin antiinflamasi yang memainkan peran pusat dalam membatasi respon imun inang terhadap patogen, sehingga mencegah kerusakan host dan mempertahankan homeostasis jaringan normal [5,6]. Pada malaria, eritrosit yang mengandung Plasmodium sp. akan dikenali Antigen Presenting Cell (APC) kemudian merangsang keluarnya Th1 ( $T$ helper-1) akan menghasilkan sitokin pro-inflamatory yaitu interferon-gamma (IFN- $\mathrm{y}$ ) dan necrosis factoralpha (TNF- $\alpha$ ) sedangkan Th-2 akan menghasilkan sitokin anti-inflamatory yaitu IL-10 dan IL-4 [7]. Keseimbangan antara sitokin yang dikeluarkan oleh Th1 serta sitokin yang dikeluarkan oleh Th2 dapat menentukan berat ringannya malaria. Tingginya rasio karakteristik TNF- $\alpha$ /IL-10 pada pasien malaria serebral mencerminkan produksi IL-10 tidak cukup untuk mencegah atau melawan penghambatan eritropoesis dan peningkatan erythrophagocytosis yang diinduksi oleh TNF- $\alpha$ dan atau mengurangi rangsangan proinflamatori [8]. Penelitian menunjukkan bahwa IL-10 dapat menghambat produksi TNF- $\alpha$, IL-1 $\beta$ dan IL-6 [9].

Meningkatnya resistensi obat anti malaria dan gangguan keseimbangan sistem imun sehingga pengobatan malaria memerlukan terapi komplementer. Di Indonesia, pengobatan malaria menggunakan Artemisinin-based Combination Therapy (ACT) [10]. Kandungan bioaktif beberapa tanaman telah terbukti memiliki efek sebagai imunomodulator termasuk sebagai imunostimulan, sehingga tanamantanaman tersebut bisa dikembangkan sebagai terapi komplementer pada malaria [11].

Bangle (Zingiber cassumunar Roxb.) merupakan rempah-rempah d.ari famili yang sama dengan kunyit (Curcuma sp.) dan telah terbukti sebagai imunomodulator. Penelitian sebelumnya membuktikan bahwa senyawa yang terkandung dalam bangle yaitu curcumin, alkaloid, flavonoid dan phenilbutanoid. Curcumin telah terbukti sebagai imunomodulator dapat meningkatkan TLR2 sebagai reseptor produksi dari IL-10 pada APC dan juga meningkatkan ekspresi CD36 pada monosit atau makrofag yang memediasi terjadinya fagositosis secara non-opsonisasi $[12,13]$. Telah dilakukan uji efektivitas tiga macam fraksi bangle dengan tiga dosis, menunjukan bahwa jenis dan dosis fraksi bangle terbaik adalah fraksi metanol Bangle ( $Z$. cassumunar Roxb.) dosis $0.017 \mathrm{mg} / \mathrm{gBB}$ mencit/hari [14].

\section{Metode Penelitian}

Penelitian ini menggunakan true experimental design secara in vivo dengan rancangan post test control group design yang menggunakan binatang percobaan sebagai subyek penelitian. Penelitian ini telah disetujui oleh komisi etik dengan nomor surat nomor 970/H.25.1.11/KE/2016.

Rimpang bangle ( $Z$. cassumunar Roxb.) didapat dari Sentra Tanaman Obat Ponorogo, di telah diidentifikasi di Herbarium Jemberiense, Jurusan Biologi, MIPA Universitas Jember. Pembuatan sediaan ekstrak rimpang Bangle dilakukan dengan cara maserasi dengan pelarut metanol 96\%. Fraksinasi dilakukan dengan tiga pelarut, yaitu $n$-heksana, diklorometana, dan metanol yang berbeda tingkat kepolarannya di dalam corong pisah sehingga didapatkan senyawa polar murni yang terkandung Bangle.

Sejumlah 25 sampel mencit galur Balb/C, umur 2-3 bulan, BB 20-30 gr dibagi dalam 5 (lima) kelompok yaitu A, B, C, D dan E. Kelompok $D$ dan $E$ mendapat imunostimulasi fraksi metanol bangle selama 14 hari. Kemudian semua kelompok mendapat infeksi $P$. berghei sejumlah $2 \mathrm{x}_{10^{7}}$ kecuali kelompok A. Setelah dilakukan hapusan darah untuk memastikan mencit telah terinfeksi P. berghei maka dimulai terapi pada kelompok perlakuan. Kelompok $\mathrm{C}$ diterapi ACT 0,0182 mg/gBB, kelompok D diterapi ACT $0,0182 \mathrm{mg} / \mathrm{gBB}$ dan fraksi metanol bangle $0,017 \mathrm{mg} / \mathrm{gBB}$, kelompok E diterapi ACT $0,0182 \mathrm{mg} / \mathrm{gBB}$. Setelah terapi lengkap selama 3 hari, mencit di narkose kemudian diambil darah intrakardial dan disentrifugasi. Kadar IL10 serum diukur menggunakan metode ELISA dengan satuan $\mathrm{pg} / \mathrm{mL}$. 
Data hasil penelitian bersifat kuantitatif dan disajikan dalam bentuk diagram kolom. Tujuan analisis data adalah uji beda antar kelompok. Analisis data menggunakan uji One Way Annova dilanjutkan dengan Post Hoc LSD Test dengan nilai signifikansi $p<0,05$. Software yang digunakan dalam pengolahan data adalah IBM SPSS versi 21.

\section{Hasil Penelitian}

Hasil penelitian menunjukkan bahwa rerata kadar IL-10 serum pada setiap kelompok adalah A 18,798 $\pm 1,60 \mathrm{pg} / \mathrm{mL}$, B 148,798 \pm $119,34 \mathrm{pg} / \mathrm{mL}, \quad$ C $84,028 \pm 30,77 \mathrm{pg} / \mathrm{mL}$, D $104,428 \pm 5,96 \mathrm{pg} / \mathrm{mL}$ dan E 74,03 $\pm 23,29$ $\mathrm{pg} / \mathrm{mL}$. Hasil rerata menunjukkan bahwa ada perbedaan kadar IL-10 serum mencit masing masing kelompok perlakuan. Data dapat dilihat pada Gambar 1.

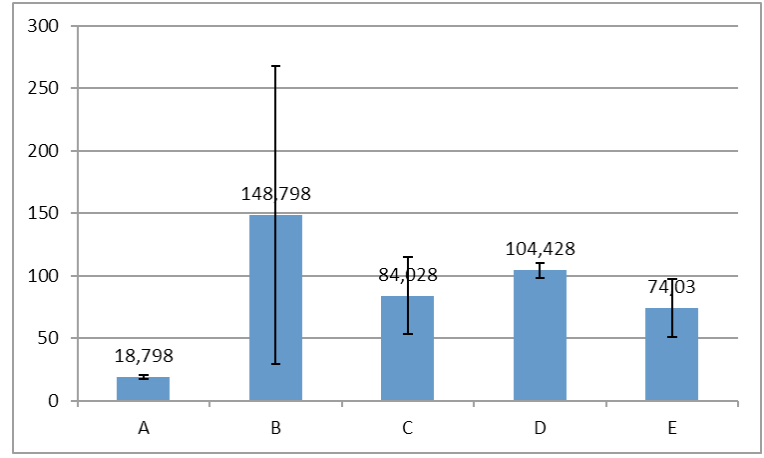

Gambar 1. Rerata kadar IL-10 serum dalam satuan $\mathrm{pg} / \mathrm{mL}$.

Data yang diperoleh di analisis menggunakan uji One Way Annova menunjukkan ada perbedaan tiap kelompok. Uji Post Hoc LSD menunjukkan kelompok $A$ signifikan dengan semua kelompok. Sedangkan antar kelompok perlakuan tidak ada perbedaan yang bermakna $(p \geq 0,05)$.

\section{Pembahasan}

Rerata kelompok A memiliki nilai yang paling rendah daripada rerata semua kelompok B, C, D, dan E yang merupakan kelompok terinfeksi $P$. berghei. Hal ini membuktikan bahwa infeksi malaria oleh $P$. berghei pada mencit Balb/C mampu meningkatkan kadar IL-10 serum. Diketahui bahwa IL-10 merupakan regulator penting pada infeksi malaria akut yang berfungsi mengontrol imun respon pada model eksperimental malaria maupun malaria pada manusia [15]. Analisis data dengan uji Post Hoc menunjukkan bahwa kelompok A terdapat perbedaan yang bermakna dengan semua kelompok $(p=0,000)$.

Rerata kelompok B memiliki nilai tertinggi diantara rerata semua kelompok. Eritrosit yang terinfeksi Plasmodium ditangkap oleh antigen presenting cell (APC) dan dibawa ke sitoplasma sel kemudian terbentuk fagosom yang akan bersatu dengan lisosom menjadi fagolisosom. Fagolisosom mengeluarkan mediator yang akan mendegradasi antigen Plasmodium menjadi peptida-peptida yang akan berasosiasi dengan molekul MHC II (major histocompatibility complex) dan di presentasikan ke sel $T C D$, selanjutnya menyebabkan aktivasi dan deferensiasi sel $\mathrm{T}$ menjadi Th1 dan Th $2[16,17]$. T helper-1 menghasilkan sitokin pro-inflamasi seperti TNFa sedangkan Th2 yang menghasilkan sitokin anti-inflamasi IL-10 [4]. Pada inflamasi akut malaria, produksi TNF- $\alpha$ oleh monosit/makrofag akan berlebihan kemudian cepat merangsang counter-regulatory produksi IL-10 yang tinggi [9]. Rendahnya rasio karakteristik IL-10/TNF- $\alpha$ dapat menentukan derajat berat ringan malaria. Rasio kurang dari 1 pada malaria berat dianggap produksi IL-10 tidak cukup untuk mencegah atau melawan penghambatan eritropoesis dan peningkatan erythrophagocytosis yang diinduksi oleh TNF- $\alpha$ dan atau mengurangi rangsangan proinflamatori [8]. Oleh karena itu dipastikan TNF- $\alpha$ pada kelompok $B$ juga tinggi, sehingga IL-10 juga diproduksi lebih banyak untuk menghambat produksi TNF- $\alpha$. Penelitian lain juga menunjukkan bahwa IL-10 dapat menghambat produksi TNF- $\alpha$, IL-1 $\beta$ dan IL-6 [9]. Analisis data dengan uji Post Hoc menunjukkan bahwa kelompok B tidak terdapat perbedaan yang bermakna dengan semua kelompok.

Rerata kadar IL-10 serum kelompok C lebih tinggi daripada kelompok E. Telah dibuktikan bahwa curcumin secara in vitro mengurangi produksi proinflamatori TNF- $\alpha$ [12]. Menurut penelitian sebelumnya hambatan produksi TNF- $\alpha$ oleh bangle ( $Z$. cassumunar Roxb.) lebih besar daripada hambatan oleh artemisin [18]. Sehingga berdasar penelitian tersebut kadar IL-10 serum pada kelompok C lebih tinggi daripada kelompok E. Namun secara statistik tidak bermakna.

Kelompok D memiliki rerata kadar IL-10 serum tertinggi dari kelompok perlakuan kemudian kelompok $\mathrm{C}$ dan kelompok $\mathrm{E}$. Hal ini disebabkan imunomodulasi oleh curcumin pada 
fraksi metanol bangle (Z. cassumunar Roxb.) meningkatkan jumLah TLR2 teraktivasi pada APC, yang kemudian memulai jalur yang memberi sinyal untuk mengaktifkan produksi sitokin IL-10 (13,19). Curcumin juga dapat mengatur pergeseran respon dari Th1 ke Th2 (20). Artemisinin yang diketahui merupakan terapi lini pertama antimalaria yang direkomendasikan WHO dapat meningkatkan respon Th2 sehingga terjadi peningkatan produksi serum IL-10 dan IL-4. Selain itu artemisinin juga memiliki aktivitas anti-inflamasi, menghambat makrofag dari melepaskan faktor inflamasi TNF-alpha dan IL-6 [21,22]. Sehingga didapatkan kombinasi artemisinin dan fraksi metanol bangle ( $Z$. cassumunar Roxb.) memiliki rerata kadar serum IL-10 yang lebih tinggi dibandingkan pemberian tunggal. Akibat penekanan produksi TNF- $\alpha$ dan peningkatan produksi IL-10 sehingga rasio IL-10/TNF- $\alpha$ yang rendah yang merupakan patogenesis malaria berat dapat dicegah.

Penelitian ini membuktikan bahwa kombinasi artemisinin dan fraksi metanol bangle (Z. cassumunar Roxb.) dapat meningkatkan IL10 tetapi hasil ini tidak memiliki perbedaan statistik yang bermakna apabila dibandingkan dengan pemberian artemisinin maupun fraksi metanol bangle ( $Z$. cassumunar Roxb.) secara tunggal $(p=0,237$ dan $p=0,121)$. Tidak adanya perbedaan yang bermakna tersebut disebabkan oleh beberapa penelitian menunjukkan IL-10 diekspresikan oleh banyak sel pada jalur imunitas adaptif maupun bawaan [13]. Sehingga peningkatan produksi IL-10 melalui jalur peningkatan pengaktifan TLR2 saja oleh curcumin tidak dapat meningkatkan kadar IL-10 serum secara bermakna.

Produksi IL-10 juga diperankan oleh imunitas spesifik yaitu sel Treg ( $T$ Regulator) yang merupakan salah satu kelas sel Th. Sel Treg mengekspresikan dan melepas IL-10 sebagai petanda supresif yang akan menekan fungsi APC dan aktivasi makrofag. Pengaktifan imunitas spesifik berbeda setiap host, mulai dari 12 jam hingga 5 hari setelah terpapar antigen [6]. Diduga perbedaan waktu tersebut menyebabkan kadar IL-10 selama 3 hari post infeksi tidak meningkatan secara bermakna. Sehingga perlu dilakukan penelitian lebih lanjut dengan waktu yang lebih dan mengurai interaksi molekuler antara sel imun adaptif dan bawaan pada pemberian fraksi metanol bangle ( $Z$. cassumunar Roxb.).

Fraksinasi menggunakan metanol pada penelitian ini bertujuan untuk memurnikan senyawa polar pada rimpang bangle ( $Z$. cassumunar Roxb.). Kandungan rimpang bangle yang berperan sebagai imunomodulator adalah curcumin yang merupakan senyawa polar. Senyawa polar yang terdapat pada rimpang bangle adalah beberapa derivat phenilbutanoid, sabine, terpinen-4, dan curcumin [23]. Ketidakmurnian fraksi metanol bangle ( $Z$. cassumunar Roxb.) menyebabkan efek imunostimulan untuk meningkatkan kadar IL-10 kurang bermakna. Sehingga perlu dilakukan skrining fitokimia terlebih dahulu serta isolasi senyawa aktif pada fraksi metanol bangle (Z. cassumunar Roxb.) untuk mengetahui secara rinci senyawa yang terkandung didalam fraksi yang dapat digunakan dalam terapi komplementer melalui peningkatan respon imun terhadap malaria.

\section{Simpulan dan Saran}

Tidak didapatkan perbedaan bermakna kadar IL-10 mencit Balb/C terinfeksi $P$. berghei dengan pemberian fraksi metanol bangle ( $Z$. cassumunar Roxb.) sebagai terapi komplementer.

Perlu dilakukan penelitian lebih lanjut untuk mengetahui kadar sitokin yang lain baik pro-inflamatori maupun anti-inflamatori dan mengurai interaksi molekuler saling mempengaruhi antara sitokin dan sel imunitas spesifik pada pemberian fraksi metanol metanol bangle ( $Z$. cassumunar Roxb.) sebagai terapi komplementer bersama ACT.

\section{Ucapan Terima Kasih}

Penulis menyampaikan terima kasih kepada DIKTI atas pendanaan penelitian ini.

\section{Daftar Pustaka}

[1] WHO (World Health Organization). Malaria ; Word Malaria Report 2015. Switzerland: World Health Organization; 2016.

[2] Balitbang Kemenkes RI. Riset Kesehatan Dasar; RISKESDAS. Jakarta: Balitbang Kemenkes RI; 2013.

[3] Isnaeni, W. Lima Orang Tewas Terjangkit Malaria. Radar Banyuwangi. 24 April 2013. p. 5.

[4] Perez-Mazliah D, Langhorne J. CD4 T-Cell Subsets in Malaria: TH1/TH2 Revisited. Frontiers in Immunology. 2014; 5: 671. 
[5] Lyer SS, Cheng G. Role of Interleukin 10 Transcriptional Regulation in Inflammation and Autoimmune Disease. Crit Rev in Immunol. 2012; 32(1): 23-63.

[6] Baratawidjaja KG, Iris R. Imunologi Dasar. ed. 10. Jakarta: Balai Penerbit Fakultas Kedokteran Universitas Indonesia; 2010. p. 228

[7] Hansen DS. Inflammatory Responses Associated with the Induction of Cerebral Malaria: Lessons from Experimental Murine Models. PLoS Pathog 2012; 8(12): e1003045.

[8] Boeuf PS, Loizon S, Awandare G, Gordon A, Tetteh KA, Addae MM, Adjei, Goka B, Kurtzhals J, Hviid L, Akanmori B, Behr C. Insights into Deregulated TNF and IL-10 Production in Malaria: Implications for Understanding Severe Malarial Anemia. Malar J.2012; 11:253

[9] Perera K, Herath P, Pathirana JS, PhoneKyaw, Alles, Mendis, Handunnetti. Association of High Plasma TNF-alpha Levels and TNF-alpha/lL-10 Ratios with TNF2 Allele in Severe P. Falciparum Malaria Patients in Sri Lanka. Pathogens and Global Health. 2013; 107(1): 21-29.

[10] Departemen Kesehatan RI. Pedoman Penatalaksanaan Kasus Malaria di Indonesia. Jakarta: Departemen Kesehatan Direktorat Jenderal P2PL. 2012.

[11] Jain V, Lucchi K, Wilson S, Blackstock W, Nagpal B, Joel D. Plasma levels of angiopoietin-1 and -2 predict cerebral malaria outcome in Central India. Malar. J. 2011; 10(383): 10.

[12] Mimche PN, Taramelli D, Vivas L. The Plant-Based Immunomodulator Curcumin as a Potential Candidate for the Development of an Adjunctive Therapy for Cerebral Malaria. Malar J. 2011; 10 (1): S10.

[13] Vathsala PG, Dende C, Nagaraj VA, Bhattacharya D, Das G, Rangarajan PN. Curcumin-Arteether Combination Therapy of Plasmodium berghei-Infected Mice Prevents Recrudescence Through Immunomodulation.PLoSONE. 2012; 7(1): e29442.

[14] Elin Y. Uji Aktivitas Fraksi Metanol Ekstrak Metanol Bangle (Zingiber Cassumunar
Roxb.) sebagai Terapi Komplementer Malaria secara In Vivo. Tidak Diterbitkan. Skripsi. Jember: Lembaga Penelitian Universitas Jember. 2015

[15] Medina TS, Costa SPT, Oliviera MD, Ventura AF, Gomes TF, Vallinoto ACR, Souza JM, Póvoa MMP, Silva JSS, Cunha MG. Increased interleukin-10 and interferon-gamma levels in Plasmodium vivax malaria suggest a reciprocal regulation which is not altered by $\mathrm{IL}-10$ gene promoter polymorphism. Malar J. 2011; 10: 264.

[16] Mading, Majemata, Rais J. Respon imun terhadap infeksi parasit malaria. Jurnal Vektor Penyakit. Balai Litbang P2B2 Donggala. Badan Litbang Kesehatan Kemenkes RI. 2014; 8(2).

[17] Muti'ah R. Penyakit malaria dan mekanisme kerja obat-obat antimalaria, Alchemy. 2012; 2(1): 80-91 dan 45-52.

[18] Arini PS, Utami WS, dan Sulistyaningsih E. Pengaruh ekstrak bangle (Zingiber cassumunar Roxb.) terhadap kadar TNF-a pada mencit yang diinfeksi Plasmodium berghei. Jurnal Pustaka Kesehatan. 2014; 2(2): 232-233.

[19] Padmanaban, G, Nagaraj VA, Rangarajan PN. Artemisinin-based combination with curcumin adds a new dimension to malaria therapy. Curr Sci. 2012; 102(5).

[20] Zhang M, Deng CS, Zheng JJ, dan Xia J. Curcumin regulated shift from Th1 to Th2 in trinitrobenzene sulphonic acid-induced chronic colitis. Acta Pharmacol Sin. 2006. 08(27IS).

[21] Chenchen S, Li HY, Hou L. Antiinflammatory and immunoregulatory functions of artemisinin and its derivatives. Mediators of Inflammation. Curr Sci. 2015; 10(25):13-17.

[22] Ho W, Eugene H, Peh HY, Chan TK, Fredwong WS. Artemisinins: Pharmacological actions beyond antimalarial. Pharmacol Ther. 2013; 142: (126139).

[23] Singh CB, Manglembi N, Swapana N, Chanu SB. Ethnobotany, Phytochemistry and Pharmacology of Zingiber cassumunar Roxb. (Zingiberaceae). J Pharmacogn Phytochem. 2015; 4: (01-06). 